\title{
肩人工骨頭置換術後の予後
}

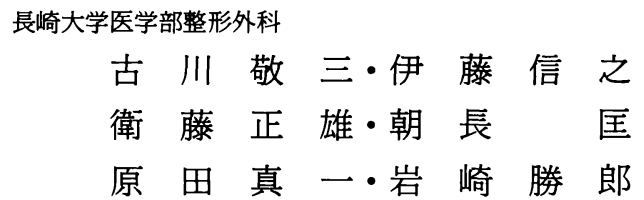

\section{Clinical Outocomes of Prosthetic Arthroplasty of the Proximal Humerus}

by

\author{
Keizo Furukawa, Nobuyuki Ito, Masao Eto, \\ Tadashi Tomonaga, Sin'ichi Harada and Katsuro Iwasaki \\ Department of Orthopaedic Surgery, \\ Nagasaki University School of Medicine
}

\begin{abstract}
We investigated the clinical results and prognosis following the use of prosthetic arthroplasty of the proximal humerus. 12 shoulders of 11 patients were investigated. Preoperative diagnosis was dislocation fracture in 6 shoulders, non-union caused by fracture in 2 shuolders, and avascular necrosis of the humeral head in 4 shoulders. The mean age at operation was 56.3 years (range ; 34 84 years). The mean follow-up period was 3 years 7 months ( 7 months -17 years 9 months). Operative results were evaluated according to the Japanese Orthopaedic Association (JOA) score.

The average postoperative JOA score for 6 cases with complications was 56.0 points $(48-67$ points). On the other hand in 6 cases without complications this was 84.7 points (74-97 points). In four cases without complications, those who had their shoulder immobilized in an elevated position, the JOA score was higher ( 88.0 points) compared to the remaining two without immobilization (78.0 points).

From the results of this study, it can be concluded that the prognosis is poor in patients with complications. Also, after prosthetic arthroplasty, if the shoulder is immobilized in an elevated position, better results can be obtained.
\end{abstract}

Key words : prosthesis (人工骨頭)， shoulder joint (肩関節)，prognosis (予後)

\section{はじめに}

上腕骨近位端骨折，骨頭壊死，変形性関節症例に対 し, 人工骨頭を用い関節の機能を再建する方法があ $る^{2)}$. 人工骨頭は, 特に 4 part fracture dislocation に対して, Neer ${ }^{5) 6}$ が優れた報告をして以来その使 用が推奖されている。しかし, 人工骨頭置換術の治療 成績は本邦では十分検討されていない。我々は人工骨 頭置換術を行った 11 例 12 肩の予後を調査し, その術 後成績に関与する因子を検討した。
対

象

1976 年から 1994 年までに当院で人工骨頭置換術を 行った 19 肩のうち, 死亡例, 痴呆等で来院不能だっ た 7 肩を除く 11 例 12 肩（男性 7 肩，女性 5 肩）を対 象とした。追跡調査期間は 7 力月 -17 年 9 力月，平 均 3 年 7 カ月であった。手術時の診断は, 上腕骨近位 端脱臼骨折，骨折後の偽関節，ステロイドによる上腕 骨頭壤死および潜函病による上腕骨頭壊死で，それぞ れ $6,2,1$ および 3 肩であった。 上腕骨頭壊死 4 肩 
は術前に日整会肩関節疾患治療成績判定基準（以下 JOA スコアー) で評価し，それぞれ 64 点, 63 点, 58 点, 67 点であった.

術前の合併症は多発外傷，同側の橈骨骨折，腋窩神 経麻疸と精神障害で, それぞれ 1 肩, 1 肩，1肩，1 例 2 肩の計 4 例 5 肩に認めた。 また術後アルフェンス シーネで挙上位に固定した 1 肩（症例 4）に術後の脱 臼を認めた。

使用した人工骨頭は Neer I 型 1 例（症例 5 ）で, 他はすべて Neer II型であった。また後療法は 1987 年以降胴体ギプスなどで, 屈曲 90 度やや外分回しの 挙上位固定を原則とした。術後 10 日目よりプーリー による他動運動を開始し，6週目より徐々に挙上肢位 を下げた．しかし合併症が原因で挙上位固定のできな かった 2 肩には三角巾による下垂固定とした。

\section{方法}

成績の評価にはJOA スコアーを用いた。また術後 固定肢位の違い, 術前術後の合併症の有無, 調査時の $\mathrm{X}$ 線像での上腕骨の短縮の有無と JOA スコアーとの 関連を調べた。なお自然下垂位の X線像で関節窝下縁 より骨頭の下縁が下方へ逸脱している例を「上腕骨の 短縮あり」と定義した。

\section{結果}

調查時の JOA スコアーは, $48 \sim 97$ 点, 平均 70.8 点であった（表 1). 疼痛（30 点満点）は 15～30 点, 平均 21 点であった。まったく疼痛のない例は 4 肩で
あった. 機能 (20 点満点) は $7 \sim 20$ 点, 平均 14 点で あった．減点の多かった項目は「頭上の棚の物に手が とどく」と「結髪動作」であり，それぞれ 10 肩 (83\%) と 6 肩 $(50 \%)$ であった。関節可動域（30点 満点）は $11 \sim 27$ 点, 平均 17 点で, 挙上角度は平均 89 度であった．X線所見評価（ 5 点満点）は $3 \sim 5$ 点, 平均 4 点で, 骨頭が下方亜脱臼位にある例を 4 肩 (33\%) に，関節窩の硬化像を術後 2 年と 3 年 6 力月 経過した 2 肩（17\%）に認めた。関節安定性（15 点 満点）は 10〜 15 点, 平均 14 点で, 脱臼不安感を 2 肩 （17\%）に認めた。受傷から手術までの期間（上腕骨 頭壊死例を除く）および手術時年齢と JOA スコアー の間に相関関係はなかった。

合併症を認めない 6 肩のうち挙上位固定とした 4 肩 と下垂位固定とした 2 肩の JOA スコアーは，前者が 平均 88 点（74 点, 85 点, 96 点, 97 点）で, 後者は 平均 80.5 点（79 点, 82 点）であった（図 1 ）。特に 可動域は挙上位固定で平均 26 点 (24 点, 24 点, 27 点, 27 点), 下垂位固定では平均 15 点（14 点, 15 点） であり, 挙上角度は前者で平均 131 度, 後者で平均 80 度であった。

調査時の X 線像で上腕骨の短縮を認めた 4 肩の JOA スコアーは平均 64 点（55〜79 点）で，短縮を 認めない 8 肩のそれは平均 74 点（48～97 点）であっ た（図 2 ）。疼痛は，短縮を認めた例で平均 21 点 （15３0 点）で, 短縮を認めない例で平均 21 点 （15〜30 点）であった. しかし可動域は，前者で平均 13 点（11〜15 点), 後者で平均 19 点（11〜27 点）で

表 1 人工骨頭置換術後の治療成績

\begin{tabular}{|c|c|c|c|c|c|c|c|c|c|c|c|}
\hline \multirow{2}{*}{ 症例 } & \multirow{2}{*}{ 年齢・性別 } & \multirow{2}{*}{ 疾患名 } & \multicolumn{6}{|c|}{ JOA スコアー } & \multirow{2}{*}{ 固定肢位 } & \multirow{2}{*}{ 上腕骨短縮 } & \multirow{2}{*}{ 合併症 } \\
\hline & & & 総合評価 & 疼痛 & 機能 & $\mathrm{ROM}$ & $\mathrm{X}$ 線 & 安定性 & & & \\
\hline 1 & 78・男性 & 脱臼骨折 & 55 & 20 & 11 & 11 & 3 & 10 & 下垂位 & あり & 同側橈骨骨折 \\
\hline 2 & 43・男性 & 脱臼骨折 & 85 & 25 & 16 & 24 & 5 & 15 & 挙上位 & なし & \\
\hline 3 & 34-女性 & 脱臼骨折 & 63 & 15 & 14 & 14 & 5 & 15 & 下垂位 & なし & 多発外傷 \\
\hline 4 & 75 -女性 & 脱臼骨折 & 67 & 20 & 18 & 11 & 3 & 15 & 挙上位 & あり & 術後脱臼 \\
\hline 5 & 52 - 男性 & 脱臼骨折 & 82 & 30 & 18 & 14 & 5 & 15 & 下垂位 & なし & \\
\hline 6 & 84- 女性 & 脱臼骨折 & 79 & 30 & 16 & 15 & 3 & 15 & 下垂位 & あり & \\
\hline 7 & 45-男性 & 骨頭壊死 & 74 & 15 & 17 & 24 & 3 & 15 & 挙上位 & なし & \\
\hline 8 & 53-男性 & 骨頭壤死 & 49 & 15 & 7 & 14 & 3 & 10 & 挙上位 & なし & 精神障害 \\
\hline 9 & 47-男性 & 骨頭壊死 & 48 & 10 & 7 & 11 & 5 & 15 & 挙上位 & なし & 精神障害 \\
\hline 10 & 35-男性 & 骨頭壊死 & 97 & 30 & 20 & 27 & 5 & 15 & 挙上位 & なし & \\
\hline 11 & 70 - 女性 & 偽関節 & 96 & 30 & 19 & 27 & 5 & 15 & 挙上位 & なし & \\
\hline 12 & 59-女性 & 偽関節 & 54 & 15 & 7 & 14 & 3 & 15 & 挙上位 & あり & 腋窩神経麻瘒 \\
\hline
\end{tabular}




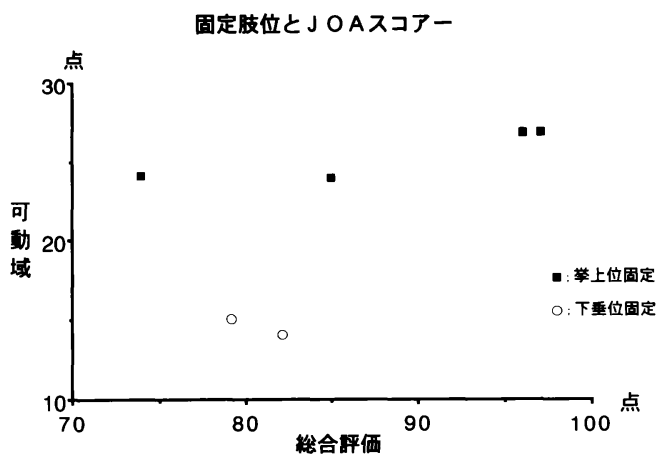

図 1 固定肢位と JOA スコアーの関係。

総合評価, 可動域ともに挙上位の固定方が良好て あった.

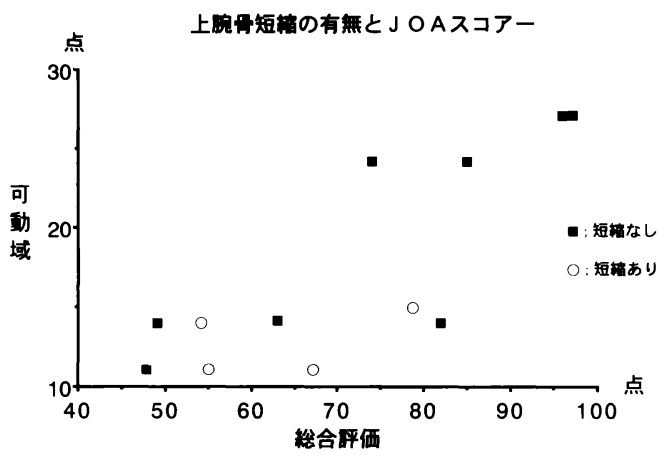

図 2 上腕骨短縮の有無と JOA スコアーの関係。 上腕骨の短縮を認めた例で良好な可動域が得られ た例はなかった。

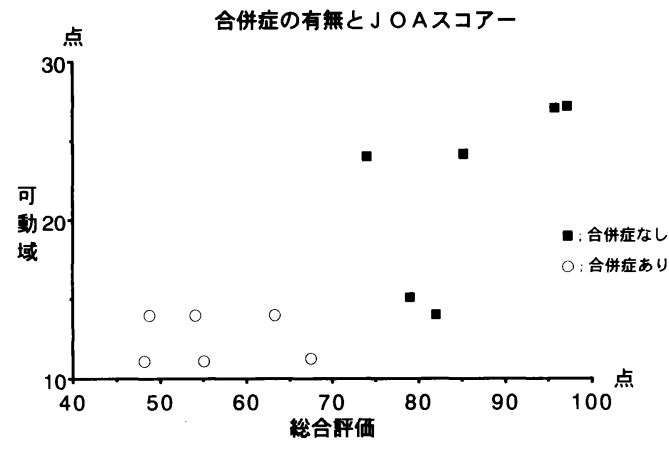

図 3 合併症の有無と JOA スコアーの関係。 合併症のない例は良好な術後成績が得られた。

あった。 また挙上角度は前者で平均 56 度, 後者で平 均 97 度であった。
合併症のある 6 肩の JOA スコアーは平均 56 点 （48～67 点）であったのに対して，合併症のない 6 肩 のそれは平均 86 点（74～97 点）であり，両者に有意 差を認めた（p<0.01）（表 4 ）。特に可動域は，合併 症のある例の平均 13 点（11〜14 点）は, 合併症のな い例の平均 22 点（14〜27 点）に比べて不良であり， 両者に有意差を認めた $(\mathrm{p}<0.01)$ ，挙上角度は前者て 平均 53 度, 後者で平均 114 度であった。術前に JOA スコアーで評価できた上腕骨頭壊死例で術後と比較す ると, 合併症のある例では術前 58 点, 63 点から術後 それぞれ 48 点， 49 点となり，合併症のない例では 67 点, 64 点から 97 点, 74 点となった。

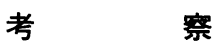

人工骨頭置換術後の予後に影響をおよほす要因とし て手術までの期間，手術時年齢，腱板機能の温存，合

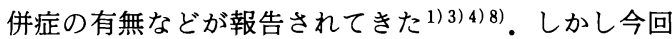
の調査では手術までの期間や手術時年齢よりも，術後 の固定肢位, 上腕骨の短縮の有無, 合併症の有無が術 後成績に影響をおよほすことが推察された。

合併症のない例で術後成績を検討した結果, 固定肢 位の違いで可動域に差を認め挙上位に固定した方が術 後成績はいい傾向にあった。挙上位固定をしたが 74 点と下垂位固定に劣った症例 7 は，挙上角度は 140 度 と良好であったが疼痛が残っていた。これは職業が建 築業で患肢を酷使していることが 1 つの大きな要因と 考えられた，肩関節の安定性や可動性に重要な役割を 果たしている腱板や三角筋の機能が正常な場合, Neer は三角巾固定での sling and sway から理学療 法を開始するよう勧めている7).しかし今回の調査は, 腱板や三角筋の機能に関わらず挙上位固定から理学療 法を開始した方がより良い可動域が得られるというも のであった．Neerのいう後療法は手技が煩雑であり， 患者の理解が得にくいことも理由の 1 つと考えられる. 即ち容易に理解を得られる挙上位固定の方が術後成績 は良かったと思われた。

上腕骨が短縮すると良好な可動域を得られないこと がわかった，短縮のない例で挙上角度が 100 度にみた なかった 4 肩のうち 3 肩は術前合併症のある例, 1 肩 は術後三角巾で固定した例であった，また短縮の有無 では疼痛に違いがなく，痛みの原因とならないことが わかった，上腕骨が短縮し骨頭が下方亜脱臼位にある と，腱板は引き伸ばされた状態になる，挙上時に引き 
伸ばされた腱板では骨頭を肩関節窩引きつけて安定さ せることができず，このため三角筋の収縮により骨頭 が上方に移動する.この scapulo-humeralrhythm の 乱れが可動域に影響をおよほしているものと考えた。 合併症の存在が術後成績特に可動域に大きく影響す ることがわかった，術前術後で比較可能であった骨頭 壊死例では, 合併症を認めた例で JOA スコアーが改 善したのに対し合併症を認めない例のそれは低下した。 合併症のために術後可動域訓練が満足に行われなかっ たり，挙上位固定をできなかったことが原因と考えた。 即ち多発外傷などで同体ギプスがまけない症例にも装 着が容易な外転装具を使用することで可動域が回復す る可能性のあることを示している.しかしアルフェン スシーネを使用した症例 4 のように術後に脱臼した例 があり, 前方脱臼を防ぐため届曲 90 度やや外分回し の固定肢位を確実とする工夫が必要であろう.

\section{ま と め}

1. 肩人工骨頭置換術を行った 11 例 12 肩を用いて その治療成績に関与する因子を日整会肩関節疾患治療 判定基準をもとに検討し, 以下の結果を得た。
2. 術後に挙上位固定とした例は, 三角巾で固定し た例に比べ, 可動域が良好であった。

3.上腕骨の短縮は，可動域に影響をおよほすこと が推測された.

4. 術前術後に合併症を有した例は, 有意に術後成 績が不良であった。

\section{参考文献}

1）保坂正人他：上腕骨近位端骨折に対する人工骨頭。整 形外科, $43: 1687-1692,1992$.

2）三笠元彦：人工骨頭 - 人工関節置換手術。手術，8： 887-897, 1979.

3）三笠元彦：上腕骨近位端骨折に対する肩人工骨頭の適 応と治療成績. 整・災外, $30: 381-388,1987$.

4）中川照彦他：上腕骨近位端骨折に対する Neer 型人工 骨頭置換術の小経験。整形外科, $40: 476-481,1989$.

5) Neer, C. S. : Displaced proximal humeral fracture (part 1). J. Bone. Joint. Surg. 52-A : 1077-1089, 1970.

6) Neer. C. S. : Displaced proximal humeral fracture (part 2). J. Bone. Joint. Surg. 52-A : 1090-1103, 1970.

7) Neer, C. S. : Recent experience in total shoulderre Placement J. Bone. Joint. Surg. 64-A : 319-337, 1982.

8）佐藤寿一他：上腕骨近位端骨折に対する Neer 型人工 骨頭の経験。整形外科, $40: 1317-1322,1989$. 